\title{
ASSOCIATION OF SJÖGREN'S AND FELTY'S SYNDROMES
}

\author{
BY \\ K. J. GURLING \\ King's College Hospital, London \\ (RECEIVED FOR PUBLICATION JULY 31, 1953)
}

Felty (1924) described five cases of chronic rheumatoid arthritis in which he had also noticed splenomegaly, a leucopenia with slight anaemia, pigmentation of the skin, and lymphadenopathy, features which have recently been reviewed by several authors, including Hutt and others (1951), Ytrehus (1946), and Hatch (1945). Sjögren (1933), Gougerot (1926), and Houwer (1927) have drawn attention to the association with rheumatoid arthritis of kerato-conjunctivitis sicca and xerostomia due to the impairment of both lacrimal and parotid gland function, a well-recognized syndrome variously named after these three authors though most frequently referred to as Sjögren's syndrome. More widespread recognition in the past decade of the many and varied aspects of this syndrome had led to more frequent diagnosis, and full accounts have been published by Sjögren (1943), Bruce (1941), Gifford, Puntenney, and Bellows (1935), Weber (1945), Henderson (1950), and Morgan and Raven (1952). A report of the histology post mortem has recently been published by Ellman, Weber, and Goodier (1951).

The two patients whose histories are reported in this paper were found to have features of both syndromes when they were examined in 1951 during the course of an investigation into the treatment of Sjögren's disease, the results of which are to be published elsewhere (Pearson, 1953). This association does not seem to have been specifically described previously, though, as will be discussed later, similar cases have been mentioned in the literature.

\section{Case Histories}

Case 1, Female, aged 61.- Her present illness began in 1946 when she developed rheumatoid arthritis in the thumbs, and later the fingers and wrists. Because the hips, knees, and feet also became involved, she sought treatment, and a leucopenia was discovered when myocrisin injections were contemplated. The arthritis had persisted with a moderate degree of activity ever since though she was never greatly incapacitated.
In September, 1951, the spleen and liver were found to be enlarged, and as the leucopenia persisted, a diagnosis of Felty's syndrome was suggested. Shortly before this time she first noticed irritation of the eyes and lids, though these symptoms were not severe. Her mouth also became dry and she had vague sore throats with frequent supefficial buccal and gingival ulcers. She had also felt tireed and in generally poor health during the previous year. $\vec{c}$

Previous History.-Recurrent bronchitis with mucoif or muco-purulent sputum. Amenorrhoea since 1939.

Family History.-None of arthritis or anaemia.

General Examination.-In November, 1951, she appeaT ed pale and anaemic, but otherwise reasonably fit. $\mathscr{O}$ he skin was dry but not pigmented and there were a petechiae on the lips, abdomen, and shins. The 7 eff parotid gland was slightly enlarged, firm, and painteser no pus could be massaged from the duct. Her tongue ws large, red, and abnormally smooth, fissured, and dry, bo no ulcers were present in the mouth. Weight 7 st. 518 . (47 kg.).

Respiratory System.-A few rales were audible ov both lower lobes.

Cardiovascular System.-Normal. Blood pressu琶 $140 / 90$.

Abdomen.-Liver smooth, firm, and considerabisy enlarged, spleen readily palpable.

Joints.-Typical chronic rheumatoid arthritis affection hands, elbows, hips, knees, and feet, with mild residual deformities. Some pain but little sign of disease activite

Lymphatic System.-A few palpable glands in the neok and both groins which were not clearly pathological; moderate splenic enlargement the only indication hyperplasia.

Laboratory Investigations (November, 1951)

Blood. Hb. 62 per cent. $(9 \cdot 2$ g.) Haldane.

Red blood cells, 3,600,000; Colour index, 0 86. ㅇ Mean cell volume, $82 \mathrm{cu}$. $\mu$; Mean cell haemoglobin concentration, 31 per cent.; Packed cell volunae, $29.5 \mathrm{~mm}$.

Platelets, 95,000 c.mm.

White blood cells, 1,100. Neutrophils, 4 per cenm; Eosinophils, 5 per cent.; Basophils, 1 per cent; Lymphocytes, 75 per cent.; Monocytes, 15 per cent. 
Basal sedimentation rate $=32 \mathrm{~mm}$. (Wintrobe uncorrected).

Bleeding time, $10 \mathrm{~min}$. (Duke's method).

Clotting time, $5 \mathrm{~min}$. (Wright's method).

Prothrombin time, $22 \mathrm{sec}$.

Serum iron $=27 \mu \mathrm{g}$. (normal 40-140).

Marrow biopsy. Sections showed moderately hyperplastic bone marrow with no clear abnormality of white cell series. No iron deposits.

Total serum proteins. $7 \cdot 55 \mathrm{~g}$. $100 \mathrm{ml}$. Albumin, $2 \cdot 88 \mathrm{~g}$.; Globulin, $4 \cdot 67$ g. A/G ratio, $0 \cdot 62 / 1$. Serum calcium, $7.9 \mathrm{mg}$.

Liver function tests. Alkaline phosphatase, 9.6 units. Thymol turbidity test, 2 units. Kunkel's turbidity test, 2 units. Total bilirubin, $0.2 \mathrm{mg}$. $/ 100 \mathrm{ml}$. Van den Bergh reaction, direct negative.

Total urinary 17-ketosteroids. 0.98 and $0.88 \mathrm{mg}$. in 24 hrs.

Histamine test meal $(0 \cdot 5 \mathrm{mg}$.). Specimens difficult to obtain and test repeated three times.

Before histamine. Free Acid $=0$. Total Acid $=$ $15 \mathrm{M} / \mathrm{E}$ litre.

After histamine. Free Acid $=0$. Total Acid $=$ $30 \mathrm{M}$ E litre.

Glucose tolerance test, normal curve.

Radiology. Chest, normal.

Joints, generalized mild decalcification of bones with typical changes of rheumatoid arthritis in hands and feet.

Parotid glands. Smears from parotid ducts: no pus cells seen. Strep. viridans and $N$. catarrhalis cultured. Salivation test (after pilocarpine $\frac{1}{6}$ gr. subcutaneously), $17 \mathrm{ml} .30 \mathrm{~min}$.

Left sialogram, a normal duct pattern.

Biopsy. Most acini well preserved, but varying degree of lymphocytic infiltration found round smaller ducts. In a few areas this infiltration was more pronounced with loss of gland tissue.

Eyes. (Mr. R. P. Crick.) 1 per cent. Bengal rose stained the exposed conjunctiva to a moderate degree, but slit-lamp examination showed a definite filamentary keratitis indicating kerato-conjunctivitis sicca.

Schirmer's test $(5 \mathrm{~mm}$. wide Whatman 41 filter paper strip), average for both eyes, $9 \mathrm{~mm}$.

Spleen: Pathological report (Professor H. A. Magnus). Weight, $777 \mathrm{~g}$; ; substance dark with unusually discrete Malpighian corpuscles. Histological architecture normal, but littoral cells proliferated and contained considerable quantities of iron, and occasional phagocytosed red cells. Some of these littoral cells appeared to contain nuclear fragments, possibly representing ingested polymorphs. A piece of liver removed at operation was normal.

Progress and Treatment.-Though the symptoms of xerostomia and kerato-conjunctivitis sicca were minimal, the special tests confirmed the diagnosis of Sjögren's syndrome. The appearance of the cornea under the slit lamp after staining with Bengal rose and fluorescein was characteristic of a filamentary keratitis, and Schirmer's test demonstrated a definite though not severe conjunctival dryness. The normal is given by Gifford and others (1943), Beetham (1935), and Rötth (1941) as above $10 \mathrm{~mm}$., and by Schirmer (1903) as at least $15 \mathrm{~mm}$., moistening of a 5-mm. wide strip of Whatman 41 filter paper in 5 minutes.

That salivation was also impaired was suggested by the dryness and glazing of the tongue in the absence of other signs of riboflavin deficiency, and the reduced flow after pilocarpine stimulation. In a series of control cases the normal response was found to vary from 25 to $75 \mathrm{ml}$. saliva in half an hour. The relatively slight histological abnormality revealed in the biopsy specimen is in keeping though the pattern was of the same nature as in eight other cases of Sjögren's syndrome subjected to parotid biop sies (Hall, 1953). The features of Felty's syndrome were well developed, the white cell count never being greater than 1,600 with an absolute granulopenia, and the bone marrow biopsy was quite compatible with this diagnosis. Because of the degree of anaemia and general malaise the patient had originally been admitted under the care of Mr. Harold Edwards for splenectomy, but as investigations on the effect of ACTH on Sjögren's syndrome were being carried out (after the report of Stephens, 1950) and since favourable effects of similar therapy in Felty's syndrome had been noted, she was given a course of ACTH to a total of $1 \mathrm{~g}$. There was a definite reduction in joint pain with a slight increase in the range of movement, but no significant subjective or objective improvement took place in the eyes or mouth. The white cell count rose to 3,000 but no dramatic leucocytosis resulted. Operation was delayed by a protracted febrile bronchitis without a leucocytosis, but on February 7, 1952, Mr. Harold Edwards carried out a splenectomy from which the patient recovered satisfactorily.

Follow-Up.-After operation she felt well, but once again there was no definite change in the condition of the eyes or mouth and the arthritis continued to cause little trouble. The white cell count rose to its highest (13,700 with 73 per cent. polymorphs) 4 days afterwards, but it later fell to 6,100 with a granulopenia of 39 per cent. After one year the patient still feels well and less languid than before the operation, but the neutropenia remains.

Case 2, Female, aged 74.- In 1897, when 18 years old, she was first troubled by rheumatoid arthritis which steadily progressed, until, at the age of 74 years, she has become crippled though not much troubled by pain. There were no symptoms suggesting Sjögren's syndrome until 1947, when her eyes became painful and watered excessively, a right corneal ulcer being discovered.

In spite of treatment, corneal scarring followed and she lost effective vision in that eye. On the left side she also had smaller ulcers and has since had much pain, grittiness, and irritation, with absence of tears and a great deal of ropey mucus. Unfortunately corneal scarring in this eye also has made her all but blind. In the same year, 1947, she also noticed dryness of the mouth with difficulty in swallowing dry foods and about this time both parotid glands began to swell. There was some pain in the right gland. A dry cough had troubled her for many years, but she had never noticed any skin irritation or indigestion.

Family History.-None of arthritis or of anaemia. 
General Examination.-A rather wizened old lady, very cheerful, but almost completely blind through atrophia bulbi with leucoma adherens on the right side and corneal scars on the left. She seemed clinically anaemic and the skin was dry and ichthyotic, but there was no purpura or pigmentation. The parotid glands were not swollen, and that on the left side appeared to have atrophied completely. The tongue was always dry and furred and salivation was obviously impaired.

Respiratory System.-A well-developed thoracic kyphosis with prominent sternum and signs of atrophic emphysema.

Cardiovascular System.--Moderate medial sclerosis of the vessels. Blood pressure $170 / 105$, but otherwise normal for her age.

Abdomen.-Spleen moderately enlarged and easily palpable; liver not clinically enlarged.

Lymphatic System.-No enlarged glands.

Joints.-Considerable deformity of fingers, hands, and wrists, indicating chronic rheumatoid arthritis with wasting of small muscles. Knees, ankles, and feet were similarly affected.

\section{Laboratory Investigations}

Blood. Hb. 57 per cent. ( $8 \cdot 4$ g.) Haldane.

Red blood cells, 3,400,000.

White blood cells, 1,900. Neutrophils, 45 per cent.; Eosinophils, 5 per cent.; Lymphocytes, 43 per cent.; Monocytes, 7 per cent.

Basal sedimentation rate, $59 \mathrm{~mm}$. (Wintrobe uncorrected).

Serum proteins, total $6.68 \mathrm{~g}$. Albumin, $3 \cdot 5 \mathrm{~g}$; Globulin, $3 \cdot 18$ g. A $\mathrm{G}$ ratio, $1 \cdot 1 / 1$.

Glucose tolerance test, normal curve.

Fractional test meal, trace of free acid only.

Radiology. Chest, changes compatible with emphysema. Joints, atrophic arthritis affecting hands, wrists, knees, and hips, also showing osteo-arthritic changes.

Total urinary 17-ketosteroids. $1 \cdot 2 \mathrm{mg}$. and $1.4 \mathrm{mg}$. in $24 \mathrm{hrs}$.

Salivation test (after pilocarpine ${ }_{6}^{1} \mathrm{gr}$.), average, $6 \mathrm{ml}$.

Eyes. Schirmer's test averaged $2 \mathrm{~mm}$. Heavy staining of left cornea and conjunctiva with 1 per cent. Bengal rose.

Marrow biopsy. Erythropoiesis normoblastic and within normal limits, no gross abnormality detectable in the white cell series, though maturation was possibly impaired.

Progress and Treatment.-The eye changes in this patient were very advanced and had been observed to progress rapidly by Professor Arnold Sorsby, under whose care she had been in 1947, and who first made the diagnosis of Sjögren's syndrome.

Salivation was much impaired at all times and lacrimation was also less than normal, Schirmer's test giving figures consistently under $3 \mathrm{~mm}$. Because of her age and the fact that she declined re-admission, parotid biopsy® was not done, and other investigations were not so $\overline{3}$ extensive as in the first case. The diagnosis of Felty's syndrome was supported by the persistent leucopenia, the white cell count never rising above 2,300 , the absence of any leukaemic change in the bone marrow, and thes definite splenomegaly. A short course of ACTH failedo to improve any of her symptoms and splenectomy was not considered worth while.

\section{Discussion}

Although attention has not previously been drawnẹ to the association of these two syndromes, the $\overrightarrow{-}$ presence of certain features of both syndromes in these two patients suggests that they have a commono pathological basis.

They are unusual variants of rheumatoid arthritis, $\vec{N}$ and of the two, Felty's syndrome is less frequently encountered than Sjögren's, the incidence of which Stenstam (1947) found to be 9.5 per cent. in $495^{\circ}$ 을 arthritic patients. Several cases of Sjögren's syndrome have been reported in which the white cell $\vec{c}$ count is low, but only Ytrehus (1946) mentions the occurrence of kerato-conjunctivitis sicca in Felty'sD syndrome. One of his patients, a woman, develope\& rheumatoid arthritis in 1927, and was found in 1939 to have kerato-conjunctivitis sicca, splenomegag $\overrightarrow{0}$ and a leucopenia of under 2,000 per c.mm. devel氶 ing later.

Examples of Sjögren's syndrome with splen megaly or leucopenia have been reported by Beetham (1935), Holm (1949), and by Cadman anch Robertson (1952), and also a somewhat unusual case्ष by Rothman, Block, and Hauser (1951) to be mentioned later. Of Beetham's nine cases with keratoo흘 conjunctivitis sicca, three had lymphadenopathy and one a palpable spleen, and one of Holm's female patients with Sjögren's syndrome had a white cell. count of 4,500 per c.mm. with 53 per cent. poly morphs, but the spleen was not palpable. Cadmang and Robertson's first case had bilateral parotioB. gland enlargement, kerato-conjunctivitis sicca, an 8 rheumatoid arthritis typical of Sjögren's syndrome together with enlargement of the spleen and livero and a white cell count of 2,000 per c.mm. with only? 17 per cent. polymorphs. Treatment with ACTH reduced the size of the liver and spleen, but no men tion of change in the white cell count is made, othero than that the neutropenia disappeared. Their secondu case also had a leucopenia of 3,000 per c.mm. with 58 per cent. polymorphs, and parotid gland swellings ${ }_{\sigma}^{\omega}$ kerato-conjunctivitis sicca, and rheumatoid arthritis. Both had elevated serum globulins of 5.65 and $5 \cdot 15$ g. per $100 \mathrm{ml}$.

The similarity to our cases is great, including the 
tendency to high serum globulins, but though these are uncommon findings in Sjögren's syndrome, Cadman and Robertson did not discuss the significance of their observations. Though a microcytic anaemia is often present in Sjögren's syndrome, as in uncomplicated rheumatoid arthritis, the only common reported disorder of the white cells is a slight lymphocytosis (Sjögren, 1943; Henderson, 1951; Stenstam, 1947).

Of thirteen cases which have been fully investigated (Pearson, 1953), only one case besides the two under discussion had a white cell count as low as 4,700 with 75 per cent. polymorphs. The report of Rothman and others (1951) concerned a man with a long history of kerato-conjunctivitis sicca and xerostomia, with recurrent parotid swellings, a white cell count of 4,300 with 76 per cent. neutrophils, splenomegaly, and a few enlarged lymph nodes. The spleen was removed and histological changes of a lymphoblastoma said to have features of Hodgkin's disease were found, dense lymphatic tissue overgrowing the normal tissue in the spleen, lymph glands, and liver. The post-mortem findings of a case of Sjögren's syndrome were reported by Reader, Whyte, and Elmes (1951), in which the spleen was slightly enlarged though the white cell count had been 9,000 per c.mm. in life; there was no abnormal lymphoid hyperplasia present in the spleen histologically.

The histology of the spleen in Case 1 showed no sign of the lymphocytic reaction typical of the parotid and lacrimal glands, and the splenomegaly cannot be attributed to secondary infection as is possible in the recurrent parotid gland swellings. Likewise no specific histological picture is found in Felty's syndrome, when, apart from hypertrophy of the malpighian corpuscles, no clear abnormality may be visible. Splenomegaly may, of course, be present in a small proportion of patients with rheumatoid arthritis in the absence of any other cause such as amyloid disease: in 5 per cent. according to Hutt and others (1951), though the figure of 1 per cent. given by Hench (1933) seems a more reasonable estimate. It seems probable that Still's disease (acute rheumatoid arthritis occurring in children and accompanied by fever, splenomegaly, lymphadenopathy, and a considerable leucocytosis) is another member of this group of diseases.

According to Schlesinger and Cathie (1951), a leucopenia and rarely agranulocytosis may develop in severe cases of Still's disease, and two cases were recorded by Collins (1937) which proceeded to typical Felty's syndrome. The liability of patient's with Felty's syndrome to develop buccal and corneal ulceration and keratitis was emphasized by Hutt and others, who attribute it to lack of resistance to infection due to the leucopenia. One of their cases had corneal ulceration, and another scleritis, corneal ulcers, and later panophthalmitis.

Nyström (1946) and Ytrehus (1946) noted corneal and buccal ulceration in their patients with Felty's syndrome, yet both these complications are frequently seen in Sjögren's syndrome when lacrimal and parotid gland secretions are deficient and the leucocytes are normal.

In the spleen removed from Case 1 (above) at operation there was no specific histological picture and certainly nothing to suggest the lymphocytic infiltration seen typically in the lacrimal and parotid glands. The leucopenia discovered in both our patients must be attributed either to depression of the bone marrow or to increased peripheral phagocytosis by a spleen which had undergone a hypertrophic change of a non-specific nature such as may be seen in hypersplenism from a variety of causes.

It seems likely that both these syndromes are associated with a similar disturbance of collagen and reticulo-endothelial tissues, and that if the spleen is enlarged to a significant degree there is added the picture of hypersplenism mainly affecting the white cell series as described by Doan (1949). A small proportion of patients with Sjögren's syndrome may therefore have a leucopenia if the spleen is enlarged, just as a few of those exhibiting Felty's syndrome may also, on closer examination, be found to have kerato-conjunctivitis and xerostomia.

\section{Summary}

Two patients have been investigated in whom features of both Sjögren's and Felty's syndromes were combined.

Though no previous report of this association has been discovered, certain similarities between these two syndromes can be found recorded in the literature.

Both syndromes are variants of rheumatoid arthritis, and should splenomegaly occur in Sjögren's syndrome the resulting hypersplenism may lead to the leucopenia typical of Felty's syndrome. No clear differentiation of the limits of the two syndromes is possible.

I am indebted to Dr. R. S. Bruce Pearson and Mr. Harold Edwards, under whose care these patients were admitted, to Professor Arnold Sorsby and Mr. R. P. Crick for their ophthalmic examinations, and to Professor H. A. Magnus and Dr. W. M. Davidson for their reports on the tissues and blood.

\section{REFERENCES} Beetham, W. P. (1935). Trans. Amer. Ophthal. Soc., 33, 413.
Bruce, G. M. (1941). Arch. Ophthal., Chicago, 26, 945. 
Cadman, E. F. B., and Robertson, A. J. (1952). Brit. med. J., 2, 68.

Collins, D. H. (1937). Rep. chron. rheum. Dis., 3, 49.

Doan, C. A. (1949), Bull N.Y. Acad Med., 25, 625.

Ellman, P. Weber, F. Parkes, and Goodier, T. E. W. (1951). Quart. J. Med. N.S. 20, 33 .

Felty, A. R. (1924). Johns Hopk. Hosp. Bull., 35, 16.

Gifford, S. R., Puntenney, I., and Bellows, J. (1943). Arch. Ophthal., Chicago, 30, 207.

Gougerot, H. (1926). Bull. méd., Paris, 40, 360.

Hall, G. F. M. (1953). Personal communication.

Hatch, F. N. (1945). Ann. int. Med., 23, 201.

Hench, P. S. (1933). J. Amer. med. Ass., 101, 2078.

Henderson, J. W. (1950). Amer. J. Ophthal. 33, 197.

Holm, S. (1949). Acta Ophthal., Kbh., Suppl. 33.

Houwer, A. W. M. (1927). Trans. ophthal. Soc. U.K., 47, 88

Hutt, M. S. R., Richardson, J. S., and Staffurth, J. S. (1951). Quart. J. Med., N.S. 20, 57.

Morgan, A. D., and Raven, R. W. (1952). Brit. J. Surg., 40, 154.

Nyström, G. (1946). Nord. med., 32, 2567.

Pearson, R. S. Bruce (1953). Personal communication.

Reader, S. M. Whyte H. M., and Elmes, P. C. (1951). Annals of the Rheumatic Diseases, 10, 288.

Rothman, S., Block, M., and Hauser, F. V. (1951). Arch. Derm. Syph., Chicago, 63, 642.

Rötth, A. de (1941). Amer. J. Ophthal., 24, 20.

Schirmer, O. (1903). v. Graefes Arch. Ophthal., 56, 197.

Schlesinger, B., Cathie, I. A. B. (1951). Annals of the Rhelumatic Diseases, 10, 415

Sjögren, H. (1933). Acta Ophthal., Kbh. Suppl. 2. English translation in 1943 by J. Bruce Hamilton, "A New Conception of Keratoconjunctivitis Sicca". Australasian Medical Publ. Co., Sydney.

Stenstam, T. (1947). Acta med. scand., 127, 130.

Stephens, C. A. L. (1950). "Proc. First Clinical ACTH Conf. Chicago, 1949", ed. J. R. Mote. Churchill, London.

Weber, F. Parkes (1945). Brit. J. Ophthal., 29, 299.

Ytrehus, O. (1946). Acta med. scand., 126, 437.
Associatión des syndromes de Sjögren et de Felty

RÉSUMÉ

On a étudié deux malades chez qui les traits des syndromes de Sjögren et de Felty coëxistaient.

Bien qu'on ne relève aucune observation précédente d'une telle association, certains points de similitude sont mentionnés dans la littérature.

Les deux syndromes constituent une variante de l'arthrite rhumatismale et chaque fois que la splénomégalie survient dans le syndrome de Sjögren, l'hypersplénisme qui en résulte peut mener à la leucopénie typique du syndrome de Felty. Il n'est pas possible demarquer nettement les limites entre ces syndromes.

Asociación de síndromes de Sjögren y de Felty Sumario

Se investigó dos enfermos en que hubo coexistencia de rasgos de síndromes de Sjögren y de Felty.

No se pudo descurbrir informe previo de tall asociación pero hállanse en la literatura ciertas similitudes entre los dos síndromes.

Ambos síndromes presentan variantes de la artritis reumatoide y siempre que la esplenomegalia ocurre en el iv síndrome de Sjögren, el resultante hiperesplenismo puede $\vec{N}$ llevar a la leucopenia típica del síndrome de Felty. No se puede demarcar claramente los límites entre estos síndromes. 